\title{
Tri Hita Karana Memoderasi Partisipasi Penyusunan Anggaran, Asimetri Informasi, dan Komitmen Organisasi terhadap Sennjangan Anggaran
}

\author{
Kadek Diviariesty ${ }^{1}$ \\ Fakultas Ekonomi dan Bisnis \\ Universitas Udayana, Indonesia
}

\author{
IGAM Asri Dwija Putri ${ }^{2}$ \\ Fakultas Ekonomi dan Bisnis \\ Universitas Udayana, Indonesia
}

\begin{abstract}
ABSTRAK
Penelitian ini bertujuan untuk mengetahui pengaruh partisipasi penyusunan anggaran, asimetri informasi dan komitmen organisasi terhadap senjangan anggaran dengan budaya Tri Hita Karana sebagai variabel moderasi. Teknik analisis yang digunakan yaitu Moderated Regression Analysis. Hasil penelitian menunjukkan bahwa partisipasi penyusunan anggaran dan komitmen organisasi tidak berpengaruh signifikan terhadap senjangan anggaran. Asimetri informasi berpengaruh positif terhadap senjangan anggaran. Interaksi antara partisipasi penyusunan anggaran dengan budaya Tri Hita Karana tidak mampu memoderasi partisipasi penyusunan anggaran terhadap senjangan anggaran. Interaksi asimetri informasi dengan budaya Tri Hita Karana mampu memperlemah pengaruh positif asimetri informasi terhadap senjangan anggaran. Interaksi antara komitmen organisasi dengan budaya Tri Hita Karana tidak mampu memoderasi komitmen organisasi terhadap senjangan anggaran.
\end{abstract}

Surel : divia5125@gmail.com

Kata Kunci: Budaya Tri Hita Karana; Partisipasi Penyusunan Anggaran; Asimetri Informasi; Komitmen Organisasi; Senjangan Anggaran.

Tri Hita Karana Moderates Participation in Budget Formulation, Information Asymmetry, and Organizational Commitment to Budgetary Slack

\section{ABSTRACT}

This study aims to determine the effect of budgetary participation, information asymmetry and organizational commitment to budgetary slack with the Tri Hita Karana culture as a moderating variable. The analysis technique used is Moderated Regression Analysis. The results showed that budgetary participation and organizational commitment had no significant effect on budgetary slack. Information asymmetry has a positive effect on budgetary slack. The interaction between budgeting participation and the Tri Hita Karana culture is unable to moderate budgetary participation against budgetary slack. The interaction of information asymmetry with the Tri Hita Karana culture is able to weaken the positive influence of information asymmetry on budgetary slack. The interaction between organizational commitment and the Tri Hita Karana culture is unable to moderate organizational commitment to budgetary slack.

Keywords: $\quad$ Tri Hita Karana; Budgetary Participation; Information Asymmetry; Organizational Commitment; Budgetary Slack.

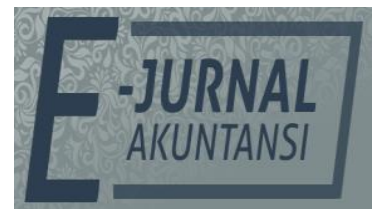

e-ISSN 2302-8556

Vol. 31 No. 1

Denpasar, Januari 2021

Hal. 32-46

DOI:

10.24843/EJA.2021.v31.i01.p03

PENGUTIPAN:

Diviariesty, K. \& Putri, I

G.A.M. (2021). Tri Hita Karana Memoderasi

Partisipasi Penyusunan Anggaran, Asimetri Informasi, dan Komitmen Organisasi Terhadap

Sennjangan Anggaran. EJurnal Akuntansi, 31(1), 32-46

RIWAYAT ARTIKEL: Artikel Masuk: 22 Desember 2020 Artikel Diterima: 23 Januari 2021

Artikel dapat diakses : https://ojs.unud.ac.id/index.php/Akuntansi/index 


\section{PENDAHULUAN}

Penganggaran memiliki peranan penting dalam perencanaan (mengidentifikasi tujuan dan tindakan yang diperlukan untuk mencapai tujuan organisasi) dan pengendalian (anggaran juga dapat digunakan sebagai kontrol). Dengan demikian, anggaran dapat digunakan untuk menilai kinerja dengan membandingkan anggaran estimasi dengan realisasinya, dan dapat mengarahkan kembali operasi jika diperlukan. Dilihat dari karakteristik anggaran, rencana anggaran yayasan dipublikasikan kepada masyarakat secara terbuka untuk dikritik, didiskusikan, dan diberi masukan. Anggaran yayasan merupakan instrumen akuntabilitas atas pengelolaan dana publik dan pelaksanaan program-program yang dibiayai dengan uang publik (Bastian 2007).

Yayasan Kesejahteraan Korpri Propinsi Bali sesuai Anggaran Dasar dan Anggaran Rumah Tangga merupakan lembaga yang bersifat sosial dan nirlaba, berorientasi pada peningkatan kualitas Sumber Daya Manusia, memfokuskan pada tiga bidang kegiatan utama meliputi: pendidikan, kesehatan, dan sosial yang operasionalnya dilaksanakan melalui Unit Pelaksana Kegiatan (UPK). Berkenaan dengan sistem tata kelola keuangan, Yayasan Kesejahteraan Korpri Propinsi Bali telah mengeluarkan Surat Keputusan Nomor 50/YAS.KORPS/IV/2017 tentang Pedoman Tata Kelola Keuangan Berbasis Kinerja sebagai pedoman pengelolaan keuangan bagi seluruh UPK dibawah yayasan, agar pengelolaan keuangan dilaksanakan secara efisien, produktif, dan akuntabel. Rencana anggaran merupakan proses punyusunan anggaran, yang diawali dengan penyusunan proyeksi pendapatan yang dihasilkan dan rencana belanja yang dibutuhkan oleh UPK dan/atau unit-unit kerja yang ada dalam lingkup UPK dalam satu tahun anggaran.

Adanya partisipasi, akan memberikan ruang kepada para pimpinan dan karyawan untuk mengapresiasikan diri terhadap target-target yang harus dicapai. (Hansen, Mowen, \& Guan 2009) menjelaskan bahwa partisipasi penganggaran dapat menimbulkan masalah potensial yaitu timbulnya senjangan dalam anggaran. Senjangan anggaran merupakan suatu fenomena yang timbul pada saat proses perencanaan anggaran, ketika pengelola diberikan kesempatan untuk berpartisipasi dalam penyusunan anggaran maka bawahan akan cenderung membuat anggaran yang mudah untuk dicapai dengan menyatakan kapabilitas atau kemampuan produktifnya lebih rendah dari yang sesungguhnya sehingga timbul senjangan anggaran. Pernyataan tersebut didukung oleh hasil penelitian yang dilakukan oleh Antari \& Sukartha (2017), Astari et al. (2018), Irfan, Santoso, \& Effendi (2016), Nasution (2020), Nurmayati, Akram, \& Yasin (2018), Priliandani \& Astika (2016), Pusporini, Haryadi, \& Herwiyanti (2018), Rahim \& Rahim (2019), Sahputra, Darwanis, \& Basri (2018), Suriani, Alam, \& Nohong (2017), Wardani Yasa \& Badera (2016), Widanaputra \& Mimba (2014) yang menyatakan bahwa partisipasi penyusunan anggaran berpengaruh positif terhadap senjangan anggaran. Pendapat lain mengatakan bahwa partisipasi dapat mengurangi terjadinya senjangan anggaran karena adanya komunikasi positif antara atasan dengan bawahan. Pernyataan tersebut didukung oleh hasil penelitian yang dilakukan oleh Chong (2017), Putri \& Ulupui (2018), Hormati et 
al. (2017), Kahar et al. (2017), Kahar, Rohman, \& Chariri (2016), Pundarika \& Dwirandra (2019), Rifqi, Subekti, \& Rahman (2017) yang menyatakan bahwa partisipasi penyusunan anggaran berpengaruh negatif terhadap senjangan anggaran. Dimana semakin tinggi tingkat partisipasi penyusunan anggaran maka semakin rendah tingkat kesenjangan anggaran yang terjadi.

Konsep teori keagenan menurut (Jensen \& Meckling 1976) hubungan keagenan antara agen dan prinsipal memiliki permasalahan yang diindikasikan dengan adanya perbedaan kepentingan dan asimetri informasi antara prinsipal dan agen. Masalah keagenan terjadi dikarenakan setiap individu ingin memaksimalkan utilitasnya masing-masing. Asimetri informasi merupakan suatu kondisi dimana prinsipal tidak mempunyai informasi yang cukup mengenai kinerja agen, baik dalam kinerja aktual, motivasi dan tujuan, sehingga atasan tidak dapat menentukan kontribusi bawahan terhadap hasil aktual organisasi. Pernyataan tersebut didukung oleh hasil penelitian yang dilakukan oleh Antari \& Sukartha (2017), Astari et al. (2018), Dewi \& Erawati (2014), Maharani \& Ardiana (2015), Nurmayati et al. (2018), Putri \& Putri (2016) yang menyatakan bahwa asimetri informasi berpengaruh positif terhadap senjangan anggaran. Hasil yang berbeda ditunjukkan dalam penelitian yang dilakukan oleh (Falikhatun 2008) menyatakan bahwa asimetri informasi berpengaruh negatif pada senjangan anggaran. Hal ini dapat terjadi karena bawahan membantu memberikan informasi pribadi tentang prospek masa depan organisasi.

Proses penganggaran melibatkan banyak karakteristik individu yang berbeda-beda, perbedaan karakteristik ini menimbulkan suatu komitmen organisasi yang berbeda pula terhadap setiap individu. Karyawan yang memiliki komitmen tinggi akan mempergunakan anggaran untuk mengejar tujuan organisasi sedangkan karyawan dengan komitmen yang rendah akan menggunakan anggaran untuk mengejar kepentingan dirinya sendiri. Semakin tinggi komitmen organisasi yang dimiliki, biasanya akan meminimalisir terjadinya senjangan anggaran. Pernyataan tersebut sejalan dengan hasil penelitian yang dilakukan oleh (Irfan et al. 2016) yang menyatakan apabila individu memiliki komitmen yang rendah terhadap organisasinya, maka peluang untuk terjadinya senjangan anggaran sangat besar, dan hasil peneltian yang dilakukan oleh (Dianthi \& Wirakusuma 2017) menemukan hasil bahwa komitmen organisasi berpengaruh negatif terhadap senjangan anggaran yang artinya semakin tinggi tingkat komitmen organisasi maka dapat mengurangi tingkat kesenjangan anggaran. Sedangkan hasil penelitian yang dilakukan oleh (Yasa \& Badera 2016) menunjukkan hasil yang berbeda, dimana komitmen organisasi tidak berpengaruh terhadap terjadinya senjangan anggaran.

Oleh karena adanya ketidakkonsistenan hasil penelitian sebelumnya, peneliti termotivasi untuk melakukan pengujian kembali terhadap pengaruh partisipasi penyusunan anggaran, asimetri informasi dan komitmen organisasi terhadap kemungkinan terjadinya senjangan anggaran. Perbedaan hasil dari penelitian sebelumnya dapat dipecahkan dengan menggunakan pendekatan kontijensi. Hal ini dilakukan dengan memasukan variabel lain yang mungkin mempengaruhi partisipasi penyusunan anggaran, asimetri informasi dan 
komitmen organisasi terhadap kemungkinan terjadinya senjangan anggaran. Variabel yang diperkirakan dapat mempengaruhi hubungan tersebut yaitu budaya Tri Hita Karana (THK).

Falikhatun (2008) menyimpulkan budaya berkaitan dengan cara seseorang menganggap pekerjaan, bekerja sama dengan rekan kerja, dan memandang masa depan. Hal ini disebabkan karena sebelum bergabung dengan organisasi, individu (pekerja) terlebih dahulu telah dipengaruhi oleh berbagai lembaga atau institusi sosial yang secara rutin menanamkan nilai-nilai dan norma-norma serta membentuk perilaku, seperti: keluarga, komunitas, bangsa, sistem pendidikan, suku dan agama. Oleh karena penelitian ini dilakukan di daerah Bali maka salah satu budaya lokal yang perlu dipertimbangkan yaitu Budaya THK. Budaya THK digunakan sebagai variabel moderasi karena Budaya THK merupakan asumsiasumsi dasar serta keyakinan yang dimiliki oleh umat Hindu di Bali dan dapat mempengaruhi cara manusia bertindak dan berprilaku dalam organisasi.

Senjangan anggaran merupakan suatu fenomena yang timbul pada saat proses perencanaan anggaran. Pada saat individu diberikan kesempatan untuk berpartisipasi dalam penyusunan anggaran maka bawahan akan cenderung membuat anggaran yang mudah untuk dicapai dengan menyatakan kapabilitas atau kemampuan produktifnya lebih rendah dari yang sesungguhnya sehingga timbul senjangan anggaran. Penelitian sebelumnya yang mendukung adanya partisipasi penyusunan anggaran terhadap senjangan anggaran yaitu (Antari \& Sukartha 2017), (Sahputra et al. 2018), dan (Panjaitan 2019). Hipotesis yang digunakan untuk menguji hubungan antara partisipasi penyusunan anggaran terhadap senjangan anggaran adalah semakin tinggi partisipasi yang di berikan kepada bawahan, maka bawahan akan berusaha agar anggaran yang disusun mudah dicapai serta mengurangi risiko yang mungkin dihadapi apabila tidak mampu mencapai target yang diinginkan dengan cara menciptakan senjangan anggaran. Hal ini sejalan dengan teori keagenan yang menyebutkan bahwa setiap individu diasumsikan akan bertindak oportunistik, yaitu mengutamakan kepentingan diri sendiri (self interest) serta cenderung untuk menghindari risiko.

$\mathrm{H}_{1}$ : Partisipasi penyusunan anggaran berpengaruh positif terhadap senjangan anggaran.

Hasil penelitian Antari \& Sukartha (2017), Astari et al. (2018), dan Maharani \& Ardiana (2015) menyimpulkan bahwa asimetri informasi dapat mempengaruhi dan meningkatkan terjadinya senjangan anggaran. Hasil penelitian tersebut sejalan dengan pernyataan yang dikemukakan oleh (Suartana 2010:139) "Senjangan anggaran akan menjadi lebih besar dalam kondisi asimetris informasi karena asimetri informasi mendorong bawahan atau pelaksana anggaran membuat senjangan anggaran". Sejalan dengan teori keagenan dan hasil dari beberapa penelitian yang searah mengenai asimetri informasi terhadap senjangan anggaran, dimana adanya asimetri informasi akan dipakai sebagai kesempatan oleh bawahan untuk bersikap oportunistik dengan memberikan informasi yang bias atau merahasiakan informasi yang dapat mempengaruhi penyusunan anggaran.

$\mathrm{H}_{2}$ : Asimetri informasi berpengaruh positif terhadap senjangan anggaran.

Allen \& Meyer (1993) menyatakan bahwa karyawan yang memiliki komitmen pada organisasinya akan bekerja dengan penuh dedikasi karena 
karyawan yang memiliki komitmen tinggi menganggap bahwa hal yang penting harus dicapai adalah pencapaian tujuan organisasi. Pernyataan tersebut sejalan dengan hasil penelitian yang dilakukan oleh (Irfan et al. 2016) yang menyatakan apabila individu memiliki komitmen yang rendah terhadap organisasinya, maka peluang untuk terjadinya senjangan anggaran sangat besar, dan hasil penelitian yang dilakukan oleh Dewi \& Erawati (2014), dan Dianthi \& Wirakusuma (2017)menemukan hasil bahwa semakin tinggi tingkat komitmen organisasi maka dapat mengurangi tingkat kesenjangan anggaran. Hal ini menggambarkan bahwa karyawan yang memiliki komitmen organisasi tinggi akan mempergunakan anggaran untuk mencapai tujuan organisasi, sedangkan karyawan dengan komitmen organisasi yang rendah akan menggunakan anggaran untuk mengejar kepentingan dirinya sendiri.

$\mathrm{H}_{3}$ : Komitmen Organisasi berpengaruh negatif terhadap senjangan anggaran

Budaya THK adalah tiga hal pokok yang menyebabkan kesejahteraan dan kemakmuran hidup manusia. Konsep ini muncul berkaitan erat dengan keberadaan masyarakat hindu di Bali (Wirawan, 2015:2). Penerapan budaya THK membuat interaksi sosial pada anggota-anggota organisasi menjadi lancar, mengurangi terjadinya konflik, dan meningkatkan efisiensi serta mengurangi adanya perilaku yang menyimpang karena tujuan dari budaya THK adalah menciptakan hubungan yang harmonis. Berkaitan dengan hubungan harmonis manusia dengan Tuhan, ada lima keyakinan dasar dalam agama Hindu (Panca Sraddha) salah satunya adalah yakin dengan adanya karma phala dari setiap perbuatan yang akan dipertanggungjawabkan secara individu kepada Tuhan. Oleh karena itu, individu cenderung akan berbuat baik dan jujur dalam setiap tindakannya termasuk dalam proses penyusunan anggaran. Hal ini juga akan meningkatkan komitmen dan loyalitas anggota organisasi, sehingga anggota akan senantiasa berpartisipasi penuh dalam memajukan organisasinya serta mendorong keinginan anggota untuk lebih mementingkan kepentingan organisasi dibandingkan kepentingan pribadinya. Oleh sebab itu, budaya THK dapat memicu adanya penurunan pada terjadinya senjangan anggaran. Penelitian (Astari et al. 2018) menyatakan bahwa budaya THK berpengaruh dan mampu memperlemah pengaruh partisipasi penyusunan anggaran terhadap senjangan anggaran.

$\mathrm{H}_{4}$ : Budaya THK memperlemah pengaruh partisipasi penyusunan anggaran terhadap senjangan anggaran.

Budaya THK telah tumbuh dan berkembang di daerah Bali, khususnya dalam masyarakat Hindu. Implementasi budaya THK pada organisasi akan sangat berpengaruh terhadap perilaku individu dalam kesehariannya seperti dapat melakukan komunikasi yang baik, saling menghormati, saling menghargai, bersikap jujur dan lain sebagainya. Hal ini akan mendorong terciptanya suasana yang harmonis dan kondusif sehingga mampu menurunkan dampak buruk yang mungkin diakibatkan oleh adanya asimetri informasi dan dapat meminimalisasi perilaku menyimpang seperti terciptanya senjangan anggaran. Astari et al. (2018) menyatakan bahwa budaya THK berpengaruh dan mampu memperlemah pengaruh asimetri informasi terhadap senjangan anggaran. 
$\mathrm{H}_{5}$ : Budaya THK mampu memperlemah pengaruh positif asimetri informasi terhadap senjangan anggaran.

Irfan et al. (2016) yang menyatakan bahwa komitmen organisasi yang tinggi dapat memperlemah terjadinya senjangan anggaran. Adanya Komitmen yang tinggi dalam diri seseorang mendorong terciptanya rasa memiliki dalam organisasi dan loyalitas dalam mencapai terciptanya tujuan organisasi, sehingga mampu meminimalisasi perilaku menyimpang seperti terciptanya senjangan anggaran. Apabila informasi yang dimiliki agen dikomunikasikan dengan baik kepada pihak prinsipal maka hal ini akan menghasilkan anggaran yang lebih realistis. Dengan begitu prinsipal atau pemegang kuasa anggaran dapat menerima informasi yang belum diketahui sebelumnya dan meningkatkan akurasi pemahaman terhadap pelaksanaan anggaran (Suartana 2010:140). Implementasi budaya THK pada organisasi akan sangat berpengaruh terhadap perilaku individu dalam kesehariannya seperti dapat berkomunikasi dengan baik, saling menghormati, saling menghargai, bersikap jujur dan lain sebagainya. Hal ini akan mendorong terciptanya suasana yang harmonis dan kondusif sehingga mampu meminimalisasi perilaku menyimpang seperti terciptanya senjangan anggaran.

$\mathrm{H}_{6}$ : Budaya THK mampu memperkuat pengaruh komitmen organisasi terhadap senjangan anggaran.

\section{METODE PENELITIAN}

Penelitian ini dilakukan pada Yayasan Kesejahteraan Korpri Propinsi Bali. Sampel yang digunakan sebanyak 118 karyawan yang berpartisipasi dalam proses penganggaran di 5 Unit Pelaksana Kegiatan (UPK). Pengumpulan data dilakukan dengan wawancara dan kuesioner. Pengukuran variabel diukur menggunakan rating-scale dengan nilai 1 sampai 10. Populasi dalam penelitian ini adalah seluruh pejabat yang ada di lingkungan Yayasan Kesejahteraan Korpri Propinsi Bali dan Sub Unit Kerja (bagian dari unit kerja) yang dibentuk oleh Yayasan. Pertimbangan yang digunakan sebagai dasar penentuan sampel dalam penelitian ini adalah para pejabat yang terlibat dalam penyusunan anggaran. Tehnik pengambilan sampel yang digunakan dalam penelitian ini adalah tehnik sampling jenuh dimana semua anggota populasi digunakan sabagai sampel. Jumlah sampel dalam penelitian ini sebanyak 118 responden. Teknik analisis yang digunakan yaitu Moderated Regression Analysis (MRA) untuk mencari pengaruh partisipasi penyusunan anggaran $\left(X_{1}\right)$, asimetri informasi $\left(X_{2}\right)$, dan komitmen organisasi $\left(X_{3}\right)$ pada senjangan anggaran $(Y)$ dengan budaya THK $(X 4)$ sebagai pemoderasi.

Adapun persamaan regresi yang dihasilkan dari model regresi moderasi dalam penelitian ini adalah:

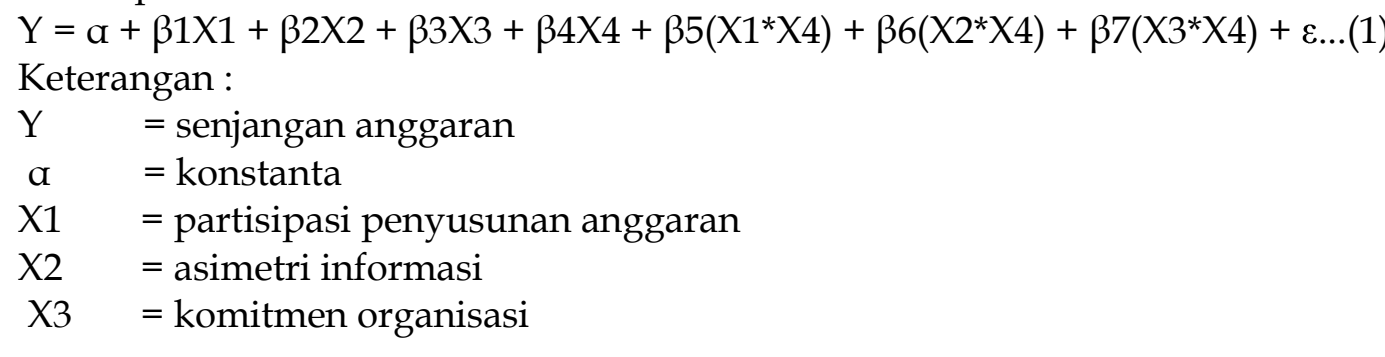




\section{X4 = budaya THK)}

$\beta 1, \beta 2, \beta 3, \beta 4, \beta 5, \beta 6, \beta 7, \beta 8=$ koefisien regresi

$\mathrm{X} 1 * \mathrm{X} 4=$ interaksi antara partisipasi penyusunan anggaran dengan budaya THK

$\mathrm{X} 2 * \mathrm{X} 4$ = interaksi antara asimetri informasi dengan budaya THK

$\mathrm{X} 3{ }^{*} \mathrm{X} 4$ = interaksi antara komitmen organisasi dengan budaya THK

$\varepsilon=$ standar error

\section{HASIL DAN PEMBAHASAN}

Statistik deskriptif dalam penelitian ini disajikan untuk memberikan informasi tentang karakteristik variabel penelitian. Untuk mengukur nilai sentral dari suatu distribusi data umumnya digunakan pengukuran rata-rata (mean), sedangkan untuk mengukur perbedaan nilai data yang diteliti dengan nilai rataratanya digunakan standar deviasi. Statistik deskriptif dalam penelitian ini dapat dilihat dalam Tabel 1.

Tabel 1. Hasil Uji Statistik Deskriptif

\begin{tabular}{lrrl}
\hline Variabel & Mean & Std. Deviation & N \\
\hline PPA (X1) & 57,30 & 10,75 & 112 \\
AI (X2) & 42,99 & 7,99 & 112 \\
KO (X3) & 71,50 & 10,67 & 112 \\
THK (X4) & 114,72 & 16,81 & 112 \\
SA (Y) & 49,68 & 9,64 & 112
\end{tabular}

Sumber: Data Penelitian, 2020

Nilai mean dari variabel menunjukkan besarnya rata-rata penerapan variabel tersebut. Nilai standar deviasi menunjukkan penyimpangan nilai variabel terhadap nilai rata-ratanya sebesar nilai standar deviasi tersebut. Nilai rata-rata variabel partisipasi penyusunan anggaran adalah sebesar 57,30. Jika dibagi dengan 8 item pernyataan akan menghasilkan nilai sebesar 7,16 yang artinya rata-rata responden memberikan skor 7 untuk item pernyataan partisipasi penyusunan anggaran. Deviasi standar variabel partisipasi penyusunan anggaran sebesar 10,75 hal ini berarti bahwa berdasarkan hasil statistik deskriptif terjadi perbedaan nilai partisipasi penyusunan anggaran yang diteliti terhadap nilai rata-ratanya sebesar 10,75.

Nilai rata-rata variabel asimetri informasi adalah sebesar 42,99. Jika dibagi dengan 6 item pernyataan akan menghasilkan nilai sebesar 7,17 yang artinya rata-rata responden memberikan skor 7 untuk item pernyataan asimetri informasi. Deviasi standar variabel asimetri informasi sebesar 7,99 hal ini berarti bahwa berdasarkan hasil statistik deskriptif terjadi perbedaan nilai asimetri informasi yang diteliti terhadap nilai rata-ratanya sebesar 7,99.

Nilai rata-rata variabel komitmen organisasi adalah sebesar 71,50. Jika dibagi dengan 8 item pernyataan akan menghasilkan nilai sebesar 8,94 yang artinya rata-rata responden memberikan skor 8 untuk item pernyataan komitmen organisasi. Deviasi standar variabel komitmen organisasi sebesar 10,67, hal ini berarti bahwa berdasarkan hasil statistik deskriptif terjadi perbedaan nilai komitmen organisasi yang diteliti terhadap nilai rata-ratanya sebesar 10,67.

Nilai rata-rata variabel budaya THK adalah sebesar 114,72. Jika dibagi dengan 13 item pernyataan akan menghasilkan nilai sebesar 8,82 yang artinya 
rata-rata responden memberikan skor 8 untuk item pernyataan budaya THK. Deviasi standar variabel budaya THK sebesar 16,81, hal ini berarti bahwa berdasarkan hasil statistik deskriptif terjadi perbedaan nilai budaya THK yang diteliti terhadap nilai rata-ratanya sebesar 16,81.

Nilai rata-rata variabel senjangan anggaran adalah sebesar 49,68. Jika dibagi dengan 7 item pernyataan akan menghasilkan nilai sebesar 7,10 yang artinya rata-rata responden memberikan skor 7 untuk item pernyataan senjangan anggaran. Deviasi standar variabel senjangan anggaran sebesar 9,64, hal ini berarti bahwa berdasarkan hasil statistik deskriptif terjadi perbedaan nilai senjangan anggaran yang diteliti terhadap nilai rata-ratanya sebesar 9,64.

Uji interaksi Moderated Regression Analysis (MRA) ini digunakan untuk menguji pengaruh variabel partisipasi penyusunan anggaran, asimetri informasi, dan komitmen organisasi terhadap senjangan anggaran dimana budaya THK sebagai variabel pemoderasi. Persamaan regresi dalam uji interaksi ini mengandung unsur interaksi (perkalian dua atau lebih variabel bebas). Hasil analisis uji interaksi dapat dilihat pada Tabel 2.

Tabel 2. Rekapitulasi Hasil Uji Interaksi (Moderated Regression Analysis)

\begin{tabular}{|c|c|c|c|c|c|c|c|}
\hline \multirow{2}{*}{ Variabel } & \multicolumn{3}{|c|}{ Unstandardized Coefficient } & \multirow{2}{*}{$\begin{array}{l}\text { Standardized } \\
\text { Coefficient } \\
\text { Beta } \\
\end{array}$} & & \multirow[t]{2}{*}{$\mathrm{T}$} & \multirow[t]{2}{*}{ Sig } \\
\hline & B & & Std. Error & & & & \\
\hline Constant & & $-0,627$ & 6,750 & & & $-0,093$ & 0,926 \\
\hline PPA & & 0,279 & 0,147 & & 0,318 & 1,894 & 0,061 \\
\hline AI & & 0,877 & 0,249 & & 0,751 & 3,515 & 0,001 \\
\hline $\mathrm{KO}$ & & 0,161 & 0,175 & & 0,183 & 0,921 & 0,359 \\
\hline THK & & 0,237 & 0,177 & & 0,435 & 1,344 & 0,182 \\
\hline PPA*THK & & $-0,001$ & 0,004 & & $-0,028$ & $-0,329$ & 0,742 \\
\hline $\mathrm{AI}^{*} \mathrm{THK}$ & & $-0,014$ & 0,006 & & $-0,264$ & $-2,226$ & 0,028 \\
\hline KO*THK & & $-0,008$ & 0,004 & & $-0,580$ & $-1,745$ & 0,084 \\
\hline Adjusted $R^{2}$ & $: 0,889$ & & & & & & \\
\hline Fhitung & $: 127,955$ & & & & & & \\
\hline Signifikan F & $: 0,000$ & & & & & & \\
\hline
\end{tabular}

Sumber: Data Penelitian, 2020

Berdasarkan Tabel 2, dapat dibuat persamaan regresi sebagai berikut.

$Y=-0,627+0,279 X 1+0,877 X 2+0,161 X 3+0,237 X 4-0,001(X 1 * X 4)-0,014(X 2 * X 4)-$ $0,008\left(X 3^{*} \times 4\right)+6,750$

Nilai konstanta sebesar -0,627 memiliki arti jika variabel partisipasi penyusunan anggaran (X1), arimetri informasi (X2) dan komitmen organisasi (X3) dinyatakan konstan pada angka 0 , maka nilai senjangan anggaran (Y) adalaha rata-rata sebesar -0,627.

Koefisien regresi pada variabel partisipasi penyusunan anggaran (X1) sebesar 0,279. Koefisien regresi yang bernilai positif memiliki arti jika partisipasi penyusunan anggaran meningkat sebesar satu satuan, maka senjangan anggaran akan meningkat rata-rata sebesar 0,279 satuan.

Koefisien regresi pada variabel asimetri informasi (X2) sebesar 0,877. Koefisien regresi yang bernilai positif memiliki arti jika asimetri informasi meningkat sebesar satu satuan, maka senjangan anggaran akan meningkat ratarata sebesar 0,877 satuan. 
Koefisien regresi pada variabel komitmen organisasi (X3) sebesar 0,161. Koefisien regresi yang bernilai positif memiliki arti jika komitmen organisasi meningkat sebesar satu satuan, maka senjangan anggaran akan menurun ratarata sebesar 0,161 satuan.

Dengan membandingkan nilai signifikansi $\beta 4$ (tidak signifikan) dengan $\beta 5$ dan $\beta 7$ (tidak signifikan) membuktikan bahwa variabel budaya THK (X4) adalah potensial moderator pada pastisipasi penyusunan anggaran (X1) dan komitmen organisasi (X3) terhadap senjangan anggaran $(Y)$.

Dengan membandingkan nilai signifikansi $\beta 4$ (tidak signifikan) dengan $\beta 6$ (signifikan) membuktikan bahwa variabel budaya THK (X4) adalah pure moderator pada asimetri informasi $(\mathrm{X} 2)$ terhadap senjangan anggaran $(\mathrm{Y})$.

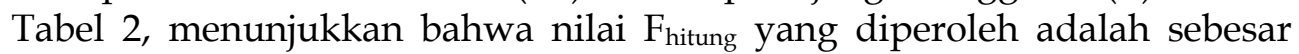
127,955 dengan signifikansi 0,000. Signifikansi ini jelas lebih kecil dari Alpha $(\alpha=$ $0,05)$ maka model regresi telah memenuhi prasyarat ketepatan fungsi regresi. Artinya model regresi moderasi ini sudah tepat digunakan sebagai alat analisis untuk menguji pengaruh partisipasi penyusunan anggaran (X1), arimetri informasi (X2) dan komitmen organisasi (X3) terhadap senjangan anggaran (Y) dengan budaya THK (X4) sebagai variabel moderasi.

Koefisien determinasi yang digunakan pada Moderated Regression Analysis (MRA) adalah nilai Adjusted R2. Hasil analisis menunjukkan bahwa nilai Adjusted $\mathrm{R}^{2}$ sebesar 0,889 . Ini berarti perubahan yang terjadi pada senjangan anggaran dapat dijelaskan oleh variabel partisipasi penyusunan anggaran, asimetri informasi, dan komitmen organisasi dengan budaya THK sebagai variabel moderasi sebesar $88,9 \%$, sedangkan $11,1 \%$ sisanya dijelaskan oleh faktor lain yang tidak diuji dalam penelitian ini.

Berdasarkan Tabel 2, diperoleh nilai $t_{\text {hitung }}$ untuk variabel partisipasi penyusunan anggaran sebesar 1,894 dan nilai signifikansi uji t sebesar 0,061 lebih besar dari $a=0,05$ dan nilai koefisien regresi sebesar 0,318 maka hipotesis pertama ditolak. Hasil ini menolak hipotesis pertama yang menyatakan partisipasi penyusunan anggaran berpengaruh positif terhadap senjangan anggaran. Artinya bahwa, tinggi rendahnya tingkat partisipasi dalam penyusunan anggaran tidak berpengaruh signifikan terhadap terjadinya senjangan anggaran. Keinginan untuk mencapai tujuan organisasi membuat pemilik dan pengelola menetapkan anggaran yang sewajarnya tanpa merendahkan pendapatan dan meninggikan biaya sesuai keadaan sebenarnya sehingga tidak berpengaruh terhadap timbulnya senjangan anggaran. Partisipasi mengarah pada komunikasi yang positif, karena dengan partisipasi akan terjadi mekanisme pertukaran informasi yang dapat menciptakan anggaran yang relevan, yang dapat diterima dan dapat dicapai. Hasil penelitian ini didukung oleh prinsip teori keagenan dimana menitikberatkan pada aliran informasi yang terperinci dari agen kepada prinsipal. Wolk, Tearney, \& Dodd (2001:100) menjelaskan Teori Keagenan memprediksikan dan menjelaskan perilaku pihak yang terlibat di sebuah organisasi, dan membangun konsep hukum dari agen. Teori keagenan berusaha menjelaskan tentang penentuan kontrak yang paling efisien yang bisa membatasi konflik atau masalah keagenan. Partisipasi penyusunan anggaran merupakan suatu proses yang melibatkan pihak prinsipal maupun agen dalam penyusunan anggaran dan memiliki pengaruh pada target 
anggaran yang ditetapkan. Berdasarkan hasil analisis, pengaruh bawahan dalam keterlibatan dan keikutsertaan berpendapat dalam penyusunan anggaran tidak berpengaruh signifikan terhadap terjadinya senjangan anggaran. Hasil penelitian ini didukung oleh penelitian dari Maryati \& Hendrawan (2020) yang menyatakan partisipasi penyusunan anggaran tidak berpengaruh terhadap senjangan anggaran.

Berdasarkan Tabel 2, diperoleh nilai thitung untuk variabel asimetri informasi sebesar 3,515 dan nilai signifikansi uji t sebesar 0,001 lebih kecil dari a $=0,05$ dan nilai koefisien regresi sebesar 0,751 maka hipotesis kedua diterima. Hasil ini mendukung hipotesis kedua yang menyatakan asimetri informasi berpengaruh positif pada senjangan anggaran. Artinya senjangan anggaran akan menjadi lebih besar dalam kondisi asimetaris informasi karena asimetri informasi mendorong bawahan atau pelaksana anggaran menciptakan senjangan anggaran (semakin tinggi asimetri informasi maka dapat meningkatkan terjadinya senjangan anggaran). Hal ini menunjukkan bahwa tingginya asimetri informasi akan dipakai sebagai kesempatan oleh bawahan untuk bersikap oportunistik dengan memberikan informasi yang bias atau merahasiakan informasi yang dapat mempengaruhi penyusunan anggaran, sehingga secara tidak langsung dapat menimbulkan adanya senjangan anggaran. Hasil penelitian ini didukung oleh prinsip teori keagenan. Konsep teori keagenan menurut Jensen \& Meckling (1976) yaitu hubungan keagenan antara agen dan prinsipal memiliki permasalahan yang diindikasikan dengan adanya perbedaan kepentingan dan asimetri informasi antara prinsipal dan agen. Hasil penelitian ini didukung oleh penelitian Antari \& Sukartha (2017), Astari et al. (2018), Dewi \& Erawati (2014), Maharani \& Ardiana (2015), Nurmayati et al. (2018), dan Putri \& Putri (2016) yang menyimpulkan asimetri informasi berpengaruh positif terhadap senjangan anggaran.

Berdasarkan Tabel 2, diperoleh nilai thitung untuk variabel komitmen organisasi sebesar 0,921 dan nilai signifikansi uji t sebesar 0,359 lebih besar dari a $=0,05$ dan nilai koefisien regresi sebesar 0,183 maka hipotesis ketiga ditolak. Hasil ini menolak hipotesis ketiga yang menyatakan komitmen organisasi berpengaruh negatif pada senjangan anggaran. Artinya bahwa tinggi rendahnya komitmen organisasi pada individu tidak berpengaruh signifikan terhadap timbulnya senjangan anggaran. Hipotesis ketiga tidak terbukti, dimungkinkan terjadi karena komitmen individu yang tumbuh merupakan upaya pemenuhan kewajiban yang dibebankan kepadanya saja. Individu dalam organisasi akan berbuat sesuatu yang menjadi tanggungjawabnya. Hasil penelitian ini didukung oleh penelitian Yasa \& Badera (2016) yang menunjukkan hasil dimana komitmen organisasi tidak berpengaruh terhadap terjadinya senjangan anggaran.

Berdasarkan Tabel 2, diperoleh nilai thitung untuk variabel pemoderasi budaya THK mempengaruhi hubungan partisipasi penyusunan anggaran dengan senjangan anggaran sebesar -0,329 dan nilai signifikansi uji $\mathrm{t}$ sebesar 0,742 lebih besar dari $a=0,05$ dan nilai koefisien regresi sebesar $-0,028$ maka hipotesis keempat ditolak. Hasil ini menolak hipotesis keempat yang menyatakan budaya THK memperlemah pengaruh positif partisipasi penyusunan anggaran terhadap senjangan anggaran. Hasil pengujian hipotesis menunjukkan bahwa budaya THK tidak mampu memoderasi hubungan 
partisipasi penyusunan anggaran terhadap senjangan anggaran. Artinya, adanya budaya THK dalam diri anggota organisasi yang berpartisipasi dalam penyusunan anggaran tidak mampu memperkuat maupun memperlemah timbulnya senjangan anggaran. Hasil penelitian ini didukung oleh penelitian sebelumnya yang dilakukan oleh (Putri \& Ulupui 2018) yang menyatakan bahwa budaya THK tidak mampu memoderasi hubungan partisipasi penyusunan anggaran terhadap senjangan anggaran, karena budaya THK merupakan sebuah persepsi yang hanya digunakan secara general dan tidak dapat diukur secara pasti.

Berdasarkan Tabel 2, diperoleh nilai thitung untuk variabel asimetri informasi sebesar -2,226 dan nilai signifikansi uji t sebesar 0,028 lebih kecil dari $\alpha=0,05$ dan nilai koefisien regresi sebesar -0,264 maka hipotesis kelima diterima. Hasil ini menerima hipotesis kelima yang menyatakan budaya THK memperlemah pengaruh positif asimetri informasi terhadap senjangan anggaran. Artinya, adanya budaya THK dalam diri anggota organisasi mampu memperlemah pengaruh positif asimetri informasi pada senjangan anggaran. Jadi, kemungkinan terjadinya senjangan anggaran menjadi lebih kecil. Hal ini menunjukkan bahwa penerapan budaya THK dapat dipergunakan sebagai suatu tata nilai atau kebiasaan yang menjadi pegangan anggota organisasi dalam melaksanakan kewajiban dan berperilaku didalam organisasi. Penerapan budaya THK yang baik dapat meningkatkan komitmen individu terhadap organisasinya meskipun pihak bawahan memiliki lebih banyak informasi dibidangnya. Hal ini juga dapat mendorong terciptanya suasana yang harmonis dan kondusif sehingga mampu meminimalisasi perilaku menyimpang seperti terciptanya senjangan anggaran. Hasil penelitian ini mendukung prinsip utama teori kontijensi. Prinsip utama teori kontijensi yaitu sistem transparansi pada suatu organisasi yang sangat berkaitan dengan interaksi untuk penyesuaian dan pengendalian lingkungan, selanjutnya dapat mempertahankan keberlanjutan usaha. Komunikasi yang baik dari berbagai pihak dapat mendorong adanya keterbukaan informasi yang dapat membuat penyusunan anggaran menjadi lebih akurat. Komunikasi yang baik juga akan menimbulkan kerjasama yang baik dalam organisasi yang berdampak terhadap perilaku individu seperti loyalitas individu terhadap organisasi sehingga mereka lebih mementingkan kepentingan organisasi dibandingkan kepentingan individu. Hasil penelitian ini didukung oleh penelitian sebelumnya yang dilakukan oleh Astari et al. (2018) yang menyatakan variabel budaya THK berpengaruh atau mampu memoderasi (memperlemah) pengaruh positif asimetri informasi pada senjangan anggaran.

Berdasarkan Tabel 2, diperoleh nilai thitung untuk variabel komitmen organisasi sebesar $-1,745$ dan nilai signifikansi uji t sebesar 0,084 lebih besar dari $\alpha=0,05$ dan nilai koefisien regresi sebesar -0,580 maka hipotesis keenam ditolak. Hasil ini menolak hipotesis keenam yang menyatakan budaya THK memperkuat pengaruh negatif komitmen organisasi terhadap senjangan anggaran. Pengujian hipotesis menunjukkan bahwa variabel budaya THK tidak mampu memoderasi hubungan komitmen organisasi pada senjangan anggaran. Artinya adanya budaya THK dalam diri anggota organisasi tidak mampu memperkuat maupun memperlemah pengaruh komitmen organisasi terhadap timbulnya senjangan 
anggaran. Hal ini dikarenakan budaya THK merupakan sebuah persepsi yang hanya digunakan secara general dan tidak dapat diukur secara pasti.

\section{SIMPULAN}

Hasil penelitian menunjukkan bahwa tinggi rendahnya partisipasi penyusunan anggaran dan komitmen organisasi tidak berpengaruh signifikan terhadap timbulnya senjangan anggaran. Semakin tinggi asimetri informasi dalam organisasi, maka timbulnya senjangan anggaran akan semakin besar. Penerapan budaya THK berpengaruh dan mampu memoderasi (memperlemah) hubungan asimetri informasi terhadap senjangan anggaran. Penerapan budaya THK tidak berpengaruh atau tidak mampu memoderasi hubungan partisipasi penyusunan anggaran dan komitmen organisasi terhadap timbulnya senjangan anggaran. Oleh sebab itu, disarankan kepada organisasi untuk lebih meningkatkan mekanisme transparansi atau pengungkapan informasi guna menghindari terjadinya senjangan anggaran dalam organisasi yang disebabkan oleh adanya asimetri informasi.

Keterbatasan dalam penelitian ini hendaknya dapat lebih disempurnakan lagi pada penelitian selanjutnya, yaitu dengan memperluas daerah pengambilan sampel sehingga dapat mewakili populasi yang lebih luas. Selain itu, penelitian selanjutnya diharapkan dapat mempertimbangkan variabel independen lain yang dapat mempengaruhi terjadinya senjangan anggaran, seperti penekanan anggaran dan ambiguitas peran.

\section{REFERENSI}

Allen, Natalie J., and John P. Meyer. (1993). “Organizational Commitment: Evidence of Career Stage Effects?" Journal of Business Research 26(1):49-61. doi: 10.1016/0148-2963(93)90042-N.

Antari, N. K. A. W., and Sukartha, I M. (2017). “Pengaruh Partisipasi Penyusunan Anggaran Dan Informasi Asimetri Pada Senjangan Anggaran Dengan Budaya Organisasi Sebagai Pemoderasi." E-Jurnal Akuntansi 20(2):929-58. doi: 10.24843/EJA.2017.v20.i02.p03.

Astari, N. P. M. Y., Sastri, I. D. A. M. M., Datrini, L. K. and Saputra, K. A. K. (2018). Pengaruh Partisipasi Penyusunan Anggaran Dan Asimetri Informasi Pada Senjangan Anggaran Dengan Budaya Tri Hita Karana Sebagai Variabel Moderasi. Vol. XXI. Samarinda.

Bastian, I. (2007). Akuntansi Yayasan Dan Lembaga Publik. Jakarta: Erlangga.

Chong, V. K. (2017). "Participative Budgeting: The Effects of Budget Emphasis, Information Asymmetry and Procedural Justice on Slack - Additional Evidence." Asia-Pacific Management Accounting Journal (APMAJ) 12(1):181220.

Dewi, N. P., and Erawati, N. M. A. (2014). “Pengaruh Partisipasi Penganggaran, Informasi Asimetris, Penekanan Anggaran Dan Komitmen Organisasi Pada Senjangan Anggaran." Jurnal Akuntansi 9(2):476-86.

Dianthi, I. A. G. P., and Wirakusuma, M. G. (2017). "Pengaruh Partisipasi Penganggaran, Asimetri Informasi, Budaya Organisasi Dan Komitmen Organisasi Pada Senjangan Anggaran." E-Jurnal Akuntansi 18(2):874-901.

Hansen, D. R., Mowen, M. M., and Guan, L. (2009). Cost Management. Enam. 
USA: South-Western Cengage Learning.

Hj. Falikhatun. (2008). "Interaksi Informasi Asimetri, Budaya Organisasi Dan Group Cohesiveness Dalam Hubungan Dan Antara Partisipasi Penganggaran Dan Budgetary Slack." Media Riset Akuntansi, Auditing Dan Informasi 8(1):65-84.

Hormati, A., Laduna, R., Mahdi, S.A.R. and Suleman H. A. K.. (2017). “The Effect of Budgetary Participation on Budgetary Slack Using Budgetary Ethical Compliance as the Mediating and Moderating Variable." International Journal of Civil Engineering and Technology 8(8):1081-92.

Irfan, M., Santoso, B. and Effendi, L. (2016). "Pengaruh Partisipasi Anggaran Terhadap Senjangan Anggaran Dengan Asimetri Informasi, Penekanan Anggaran Dan Komitmen Organisasional Sebagai Variabel Pemoderasi." Jurnal Akuntansi Dan Investasi 17(2):158-75. doi: 10.18196/jai.2016.0052.158175.

Jensen, M. C., and Meckling, W. H. (1976). "Theory of the Firm: Managerial Behavior, Agency Costs and Ownership Structure." Journal of Financial Economics 3(4):305-60. doi: 10.2139/ssrn.94043.

Kahar, S. H. A., Hormati, A., Laduna, R., and Mahdi, S.A.R. (2017). "The Effect of Budgetary Participation on Budgetary Slack Using Budgetary Ethical Compliance." International Journal of Economics and Business Administration $5(2): 83-99$.

Kahar, S. H. A., Rohman, A. and Chariri, A. (2016). "Participative Budgeting, Budgetary Slack and Job Satisfaction in the Public Sector." Journal of Applied Business Research 32(6):1663-74. doi: 10.19030/jabr.v32i6.9814.

Maharani, A. A. I., and Ardiana, P. A. (2015). "Pengaruh Partisipasi Penganggaran, Komitmen Organisasi, Dan Ketidakpastian Lingkungan Pada Senjangan Anggaran." E-Jurnal Akuntansi 12(3):770-85.

Maryati, Sr., and Hendrawan, R. (2020). "Budgetary Slack: Information Asymmetry and Emphasis of Budgetary As Moderating Effect." Akuntabilitas 14(2):243-52. doi: 10.29259/ja.v14i2.11780.

Mukaromah, A., \& Suryandari, D. (2015). Pengaruh Partisipasi Anggaran, Asimetri Informasi, Komitmen Organisasi, Ambiguitas Peran Terhadap Budgetary Slack. Accounting Analysis Journal, 4(4), 1-8, ISSN: 2252-6765.

Nasution, D. A. D. (2020). "Effect of Budgetary Participation on the Budgetary Slack with Information Asymmetry, Environmental Uncertainty, and Budget Emphasis as Variables Moderation." Journal of Business Management and Technology 4(2):113-20.

Nurmayati, Mila, Akram, and Yasin, M. (2018). “Effect Of Participatory Budget, Information Asymmetry, Organization Commitment, Budget Emphasis And Individual Capacity Toward Budgetary Slack In Local Government In Central Lombok, Indonesia." International Journal of Economics, Commerce and Management 6(7):179-95.

Priliandani, N. M. I., and Astika, I. B. P. (2016). "Pengaruh Partisipasi Penganggaran Pada Senjangan Anggaran Di Universitas Udayana Dengan Informasi Asimetri Dan Motivasi Sebagai Pemoderasi." Jurnal Ekonomi Dan Bisnis 5(4):749-74.

Pundarika, I. G. P., and Dwirandra, A. A. N. B. (2019). “The Effect of Budget 
Participation on Budgetary Slack with Organizational Commitments and Love of Money as Moderation." International Journal of Science and Research 8(2):491-96.

Putri, I G. A. M. A., and Ulupui, I G. K. A. (2018). “The Influence Of Participative Budgeting On Budgetary Slack \With Local Culture And Corporate Governance As The Moderators: An Empirical Study On Rural Banks (Bprs) In Bali." Russian Journal of Agricultural and Socio-Economic Sciences 6(78):11928. doi: https:// doi.org/10.18551/rjoas.2018-06.13.

Pusporini, I. D., Haryadi, and Herwiyanti, E. (2018). "The Effect of Budget Participation on Budgetary Slack with Information Asymmetry and Organizational Commitment as a Moderating Variable." Journal of Research in Business, Economics and Management 12(1):2261-69.

Putri, G. A. M. C., and Putri, I. G. A. M. A. D. (2016). "Pengaruh Kejelasan Sasaran Anggaran, Karakter Personal Dan Information Asymmetry Pada Senjangan Anggaran." Jurnal Akuntansi 14(3):1555-83.

Rahim, Reza, M., and Rahim, S. (2019). "Pengaruh Partisipasi Anggaran Terhadap Senjangan Anggaran Dengan Asimetri Informasi, Ketidakpastian Lingkungan, Dan Penekanan Anggaran Sebagai Variabel Moderasi." Jurnal Akuntansi Aktual 241-49.

Rifqi, Abdullah, R., Subekti, I., and Rahman, A. F. (2017). "The Effect of Budget Participation to Budgetary Slack With External Pressure as Moderating Variable." Journal of Accounting and Business Education 2(1):178-201. doi: 10.26675/jabe.v1i1.9757.

Sahputra, Ilham, Darwanis, and Basri, H. (2018). "Pengaruh Penganggaran Partisipatif, Gaya Kepemimpinan Dan Perilaku Penyusun Anggaran Terhadap Slack Anggaran (Studi Pada Satuan Kerja Perangkat Kabupaten Pemerintah Aceh Selatan)." Jurnal Perspektif Ekonomi Darussalam 4(1):19-30. doi: 10.24815/jped.v4i1.10920.

Suartana, I. W. (2010). Akuntansi Keprilakuan Teori Dan Implementasi. Yogyakarta: CV Andi Offset.

Suriani, Seri, Alam, S. and Nohong, M. (2017). "Moderation Of Information Asymmetry, Self Esteem To The Effect Of Participatory Budgeting On Budgetary Slack." Advances In Economics, Business And Management Research 40(2):175-83.

Wardani Yasa, S., Sri, M. A. and Badera, I D. N. (2016). "Peran Komitmen Organisasi Dan Satuan Kerja Perangkat Daerah Dalam Memoderasi Pengaruh Partisipasi Penganggaran Pada Senjangan Anggaran." Jurnal Ekonomi Dan Bisnis 5(4):905-30.

Widanaputra, A. A., and Mimba, N. P. S. H. (2014). “The Influence of Participative Budgeting on Budgetary Slack in Composing Local Governments' Budget in Bali Province." Procedia - Social and Behavioral Sciences 164:391-96. doi: 10.1016/j.sbspro.2014.11.093.

Wirawan, I. M. A. (2015). Tri Hita Karana, Kajian Teologi, Sosiologi, Dan Ekologi Menurut Veda. Paramita.

Wolk, H. I., M. G., Tearney, and Dodd, J. L. (2001). Accounting Theory: A Conceptual and Institutional Approach. Fifth. Cincinnati, Ohio: South Western Collage Publishing. 
Yayasan Kesejahteran Korpri Propinsi Bali. Keputusan Yayasan Kesejahteran Korpri Propinsi Bali Nomor 50/YAS.KORPS/IV/2017 tentang Pedoman Tata Kelola Keuangan Berbasis Kinerja Yayasan Kesejahteran Korpri Propinsi Bali. (2017). Denpasar. 